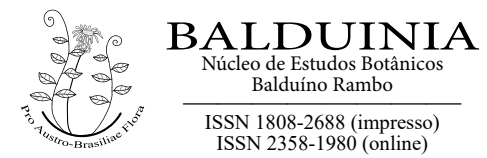

BALDUINIA, ano XVII, nº 67: 26-30. 2021

Publicado em 4 de junho de 2021. DOI: $10.5902 / 2358198066129$

\title{
Cypella trimontina Ravenna (Iridaceae) a rare species micro-endemic in the Paraje Tres Cerros, La Cruz, northeast Argentina
}

\author{
Leonardo Paz Deble ${ }^{1,3}$ Fabiano da Silva Alves ${ }^{2,3}$
}

\begin{abstract}
Resumen. Cypella trimontina Ravenna (Iridaceae) una especie rara micro endémica en la Paraje Tres Cerros, La Cruz, nordeste de la Argentina. Nuevos datos para Cypella trimontina Ravenna son presentados. La especie es una de las más raras del género, ocurriendo únicamente em los tres cerros que hacen parte de la Paraje Tres Cerros, en el municipio de La Cruz, provincia de Corrientes, Argentina.

Palabras-clave: Capará, Chico, Corrientes, Nazareno, San Martin, sección Cypella.
\end{abstract}

\begin{abstract}
Cypella trimontina Ravenna (Iridaceae) a rare species micro-endemic in the Paraje Tres Cerros, La Cruz, northeast Argentina. New data on Cypella trimontina Ravenna are presented. This species is one of the rarest of the genus, occurring exclusively in the three hills that make up Paraje Tres Cerros, in La Cruz municipality, Corrientes province, Argentina.

Key words: Capará, Chico, Corrientes, Nazareno, San Martin, section Cypella.
\end{abstract}

The genus Cypella Herbert (1826: pl. 2637) comprises 32 species of bulbous plant with pleated leaves (Deble \& Alves 2020, Deble 2021), almost totally confined to complex of grasslands ecosystems of Río de La Plata (RPG), the most extensive area of grasslands in Southeastern South America (Azpiroz et al. 2012). Cypella displays a meaningful number of endemic species, several of them threatened and having reduced geographic distribution. All species with reduced geographic range occur in environments with specific characteristics, and depending on the species, the bulbs develop since moist soils to cleft in the rocks; however, in the same species, there is usually no variation in occurrence and habitat conditions (Deble \& Alves 2020, Deble 2021).

The environments with major number of endemism are the following: (1) small rivers of fast-flowing water, (2) periodically inundated grasslands and bogs, (3) stony grasslands, (4) rocky crevices, (5) in half shade associated with shrubby community, (6) edge of forest formations, and (7) slope of hills, while more common species grow mainly on grasslands with different soil depths and soil types (Ravenna 1977, Deble \&
Alves 2017a, 2017b, Deble 2021). Places as hills are particularly important, because they form in many cases singular environments that stay isolated from their surroundings areas, and the species pass through different evolutionary processes, resulting in a high level of local endemism (Heald 1951, Kristensen \& Frangi 1995). Three species of Cypella are known exclusively in these environments: C. gloriana Deble \& F.S. Alves, C. magnicristata Deble and C. trimontina Ravenna. The first-one species is endemic in the base and slope of hill Cerro da Glória, São Vicente do Sul municipality, central Rio Grande do Sul state (RS), Brazil (Deble et al. 2015b). The second species, is registered on the base of the hills of Jarau locality, Quaraí municipality, and on Caverá mountainous range, Santana do Livramento municipality, both places in southwest RS (Deble et al. 2012, Deble $\&$ Alves 2020), while C. trimontina is one of the rarest and poorly known species of Cypella, registered only in the hills of Paraje Tres Cerros, Corrientes province, Argentina (Ravenna 2009, Cajade et al. 2013a, Deble et al. 2015a, 2015b).

Paraje Tres Cerros is located in the municipality of La Cruz, southern of General San Martín

\footnotetext{
Accepted on November 10, 2020.

${ }^{1}$ Universidade Federal do Pampa - Unipampa campus Dom Pedrito, Rua 21 de abril 80, CEP 96450-000. E-mail: deble.biol@gmail.com (author for correspondence).

${ }^{2}$ Curso de Ciências Biológicas, Universidade da Região da Campanha, Praça Getúlio Vargas 47, Alegrete, Rio Grande do Sul, $97542-570$, Brazil. E-mail: alves.fs.bio@gmail.com

${ }^{3}$ Núcleo de Pesquisas Botânicas Balduíno Rambo, Universidade Federal de Santa Maria, Av. Roraima, CEP 97105-900.
} 
Department, in central east Corrientes Province, Argentina. This singular area belongs to district of "Campos", within the "Paranaense Province" (sensu Cabrera 1976, Cabrera \& Willink 1980), and is entirely located in the region of "Northern Campos" in Argentina (sensu Bilenca \& Miñarro 2004, Azpiroz et al. 2012), being characterized by the grasslands associated to bogs and gallery forest. Geologically, Paraje Tres Cerros consists of a rock outcrop made of quartz sandstone dating from the Late Jurassic to the Early Cretaceous (Herbest \& Santa Cruz 1999). These three hills are isolated, since they are surrounded by the vast plains of Corrientes, and are locally denominated "El Nazareno" (179 m a.s.1.), "El Capará" (158 m a.s.1.), and "El Chico" (148 $\mathrm{m}$ a.s.1.). These three mountains are the only ones found in the entire province and neighboring regions (Cajade et al. 2013a, Cajade et al. 2013b). They represent an isolated environment characterized by singular microhabitats of rocky grassland, and with a surprising number of exclusive taxa, including the plants Amaryllis euryphylla Ravenna (Ravenna 2003), Gymnocalycium Angelae Meregalli (Meregalli 1998), and the lizard endemic Homonota taragui (Cajade et al. 2013a).

Cypella trimontina was described by Ravenna (2009) based in a single collection made by the prolific botanist Angel Lulio Cabrera (1908-1999) in the year 1976; nevertheless, this species was not found in nature since this voucher. During collections performed in the type locality of $C$. trimontina, topotypical populations of this species were found, and with the addition of new vouchers and analyzes of live specimens was possible to obtain new data about this taxon, which is described and illustrated, and comments about geographic distribution, phenology, conservation and relationships are also presented.

\section{Material and methods}

To conduct this study, collections from wild populations of Cypella were performed in the locality of Tres Cerros and also in others parts of northeastern Argentina (Corrientes, Entre Ríos, and Misiones Provinces), to verify the geographic distribution and extent of occurrence of $C$. trimontina Ravenna. Additionally were evaluated over 5,000 specimens of Cypella (including digital images) deposited in the following herbaria: B, CORD, CTES, FCQ, FLOR, G, HAS, HBR, ICN, K, LP, MVM, MVFA, MVFQ, NY, P, PACA, PY,
R, RB, SGO, S, SI, SP, and US (herbaria acronym follows Thiers 2021). The morphological description is based on the examined material, and the terminology follows Goldblatt \& Manning (2008), and Beentje (2010).

\section{Results and discussion}

Cypella trimontina Ravenna, Onira Bot. Leaflets 12 (1): 2. 2009. Type: ARGENTINA. Corrientes: San Martín, La Cruz, Tres Cerros, 22 October 1976, A. L. Cabrera 28162 (Holotype SI!, isotype CTES!). Figure 1.

Plant up to $10-28 \mathrm{~cm}$ high above the soil, underground stems $6-8 \mathrm{~cm}$ long. Bulb subglobose or ovoid, 20-38 × 20-36 mm, prolonged in a collar 2-4 cm long; cataphylls dark-brown, broadly ovate-lanceolate, apex acuminate. Basal leaves at anthesis absent or up to 2 , blades elliptic-lanceolate, firm in texture $6-25 \times 0.2-0.5 \mathrm{~cm}$. Cauline leaf linear-ensiform, rigid, $3.5-6 \times 0.2-0.3 \mathrm{~cm}$, base attenuate. Flowering stems $8-15 \mathrm{~cm}$ long, furcated in distal half. Spathes 1-2 per branch, 3.4-4.7 × 0.3-0.4 cm, herbaceous, pallid-green, bivalved, one-flowered, pedunculate, peduncles $3.2-5.5 \mathrm{~cm}$ long; outer valve $2.1-2.6 \mathrm{~cm}$ long, the inner $3.5-4.7 \mathrm{~cm}$ long, both obtuse at the top, with membranous and hyaline edges covered with sparse parallel dark brown longitudinal glandular strips; pedicel filiform, $3.5-4.5 \mathrm{~cm}$ long. Flowers 38-44 mm diameter, yellow or golden yellow, shiny, the concave part with a central brown stripe in the distal part; central concavity $10-12 \mathrm{~mm}$ diameter, and 6-8 $\mathrm{mm}$ deeper. Tepals whorls sharply dissimilar. Outer tepals oblong, 18-28 mm long, yellow or golden-yellow, yellow veined, concave at the base for $8-9 \mathrm{~mm}$; blades yellow or golden-yellow, with a central brown stripe in the proximal half, $12-20 \times 12-13 \mathrm{~mm}$, pandurate, reflexes, apices truncate or rounded, apiculate; claws cuneate, 8-9 mm long, 2-2.5 $\mathrm{mm}$ wide at the base, and 7.5-8 mm wide at the apex, dull-yellow or dull-orange. Inner tepals geniculate-recurved, 9-10 $\times 6-7 \mathrm{~mm}$, the proximal half patent, slightly inclined, then curved upward, the distal one-third incurved and strongly reclinate; blades yellow or golden-yellow, with a white-cream central depression densely covered with golden-yellow or bright-yellow one-celled lipid trichomes at the base (carpet of elaiophores), surrounded by a lateral high part, with reddish-brown parallel stripes and few stains; claws cuneate, 6.5-7 $\mathrm{mm}$ long, $c a$. $2 \mathrm{~mm}$ wide at the base, and $4-4.5 \mathrm{~mm}$ wide at 


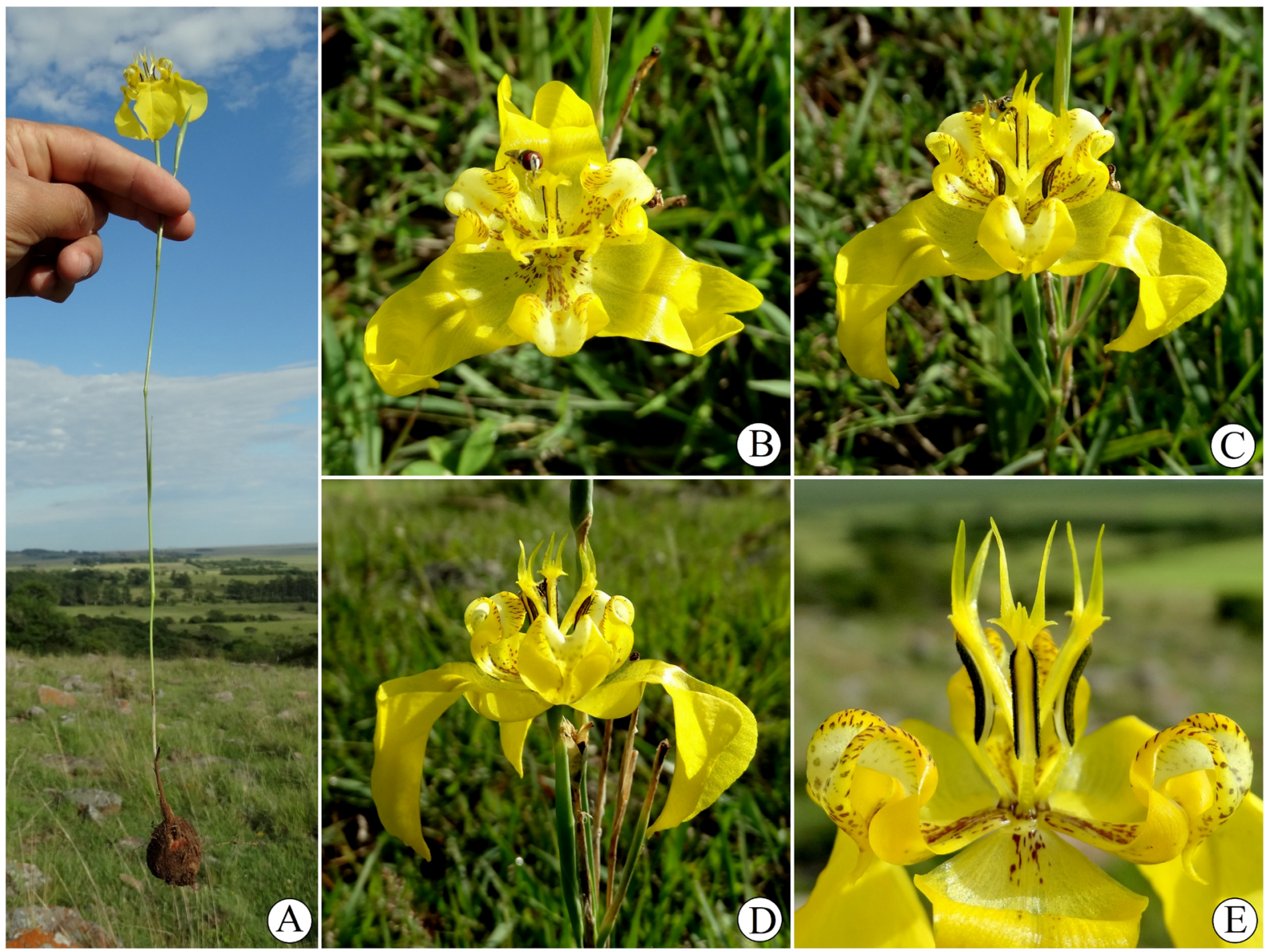

Figure 1. Cypella trimontina. A. General aspect. B. Flower, upper view. C. Flower, inclined view. D. Flower, lateral view. E. Detail of stamens and gynoecium.

the apex, reddish-brown, with dark-purple parallel stripes. Filaments narrowly obclavate $4-4.8 \mathrm{~mm}$ long, porrect, dull-yellow, slightly hyaline, base abruptly thickened, purplish, attached for $0.2-0.3$ $\mathrm{mm}$; anthers oblong 7.5-8 $\times 2-2.2 \mathrm{~mm}$; dull-yellow, white-cream on both margins, locules darker, pollen dark-grey. Ovary pallid-green, oblong 9-10 $\times 1.8-2.2 \mathrm{~mm}$. Style (including style-branches and crests) $14.5-18.5 \mathrm{~mm}$ long. Style branches channeled, porrect, 7-9 mm long, crests at the apex 3, translucent and yellowish, adaxial crests deltate to lanceolate, $2.5-6.5 \mathrm{~mm}$ long, abaxial crest deltate, at apex shortly bifid, 1-2 mm long. Capsule obovate-oblong, 9-10 × 3.5-4.5 mm. Seeds obconic, 2-2.5 mm, angled, reddish-brown, epidermis minutely faveolate.

Phenology - Specimens with flowers and capsules can be found from October to December, but probably can flourish sporadically after the rain.
The flowers bloom in the morning and wither midday. In cloudy days, the flowers remain opened up to early afternoon. During our field activities was observed two species of hoverfly (Sirphydae) hovering or nectaring at flowers.

Etymology - The specific epithet "trimontina" means three mountains, and refers at type locality, Paraje Tres Cerros, in the municipality of La Cruz, where this species is endemic (see Ravenna 2009: 3).

Additional specimens examined-ARGENTINA. Corrientes: San Martín, Paraje Tres Cerros, Cerro El Chico, "na encosta leste, próximo ao topo", 22 December 2014, L. P. Deble \& F. S. Alves 15992 (SI!); idem, flores amarillas, 16 December 1979, A. Schinini et al. 18529 (CTES!).

Distribution and Habitat-Cypella trimontina has 
its geographic range estimated in less than $20 \mathrm{~km}^{2}$, since this species is micro-endemic in the locality of Paraje Tres Cerros, La Cruz municipality, San Martin Department, center-east Corrientes Province. The individuals occur only in slope, on the north face of the hills, on stony grasslands associated to rocks, made of quartz sandstone of Botucatú geological formation (according Aceñolaza 2007).

Conservation - Cypella trimontina is one of the species that has smaller geographic distribution, since the individuals are isolated in the slope of the three hills of Paraje Tres Cerros, and they need specific habitat, on well-drained stony-grasslands, associated to large rocks. Furthermore, around the hills, the environment is different, and C. trimontina probably does not have as expanding its geographic range. According to IUCN Red List assessment protocol (2019) the species can be assigned as Critically Endangered, based in the following criteria: CR B1, B2bc (i, ii, iii), and D.

Discussion-Cypella trimontina is related to $C$. armosa Ravenna, which also occurs in the same Argentinian Province. However, C. armosa spreads in different habitat, because grows exclusively on low and periodically inundated grasslands and bogs. Furthermore, C. armosa displays narrowly cuneate inner tepals (while in C. trimontina are broadly cuneate), and obclavate and shorter staminal filaments (while in $C$. trimontina are narrowly obclavate and longer). Ravenna (2009: 2-3) also mentioned the different color of perigone (orange in C. trimontina vs. yellow in C. armosa), and shorter crests of $C$. trimontina as attributes to distinguish both species. However, during analyses of live specimens of $C$. trimontina was verified crests reaching $6.5 \mathrm{~mm}$ long, and the flowers are yellow or golden-yellow. Cypella trimontina is closely related to $C$. magnicristata, an endemic species of southwest RS, Brazil, which the most close populations are distant about $c a$. of $120 \mathrm{~km}$ of the locality of Paraje Tres Cerros; however, $C$. trimontina differs by its rigid leaves, and small size of perigone and narrower inner tepals. The morphologic similarity between $C$. trimontina and C. magnicristata is quite interesting in a phytogeographic point, since the two species may have had a common ancestor with the geographic distribution that stretched between the two regions of hills in the past, which survived only in isolation in the hills and went through the speciation process. Molecular analyses disentangling relationships between both species and with $C$. armosa will be necessary to test this hypothesis and elucidate the phylogenetic and phytogeographic history of these species.

\section{References}

Aceñolaza, F.G. 2007. Geología y recursos geológicos de la Mesopotamia Argentina. Instituto Superior de Correlación Geológica (INSUGEO), Serie Correlación Geológica 22,160 pp.

Azpiroz, A.B., J.P. Isacch, R.A. Dias, A.S. Di Giacomo, C.S. Fontana \& C.M. Palarea. 2012. Ecology and conservation of grassland birds in southeastern South America: a review. Journal of Field Ornithology 83(3): 217-246. http://dx.doi.org/10.1111/j.1557-9263.2012.003072.x

Beentje, H. 2010. The Kew Plant Glossary: an illustrated dictionary of plant terms. Royal Botanic Gardens, Kew, $160 \mathrm{pp}$

Bilenca, D. \& F. Miñarro. 2004. Identificación de áreas valiosas de pastizal en las Pampas y Campos de Argentina, Uruguay y Sur de Brasil. Fundación vida silvestre, Buenos Aires, $19 \mathrm{pp}$.

Cabrera, Á.L. 1976. Regiones Fitogeográficas Argentinas. Enciclopedia Argentina de Agricultura y Jardinería Tomo II, Fascículo 1. Acme, Buenos Aires, 85 pp.

Cabrera, Á. L. \& A. Willink. 1980. Biogeografia de América Latina. Secretaría General de la OEA, Monografía, 13, $122 \mathrm{pp}$.

Cajade, R., E.G. Etchepare, C. Falcione, D.A. Barrasso \& B.B. Alvarez. 2013a. A new species of Homonota (Reptilia: Squamata: Gekkota: Phyllodactilidae) endemic of the hills of Paraje Tres Cerros, Corrientes Province, Argentina. Zootaxa 3709 (2): 162-176.

Cajade R., W. Medina, R. Salas, B. Fandiño, A. García, I Pautasso, A. Piñeiro, J. M., Acosta, J.L. Zaracho, V., Avalos, A. Gómez, F. Odriozola, M. P. Contreras, F.I. Hernando \& B.B. Álvarez . 2013b. Las islas rocosas del Paraje Tres Cerros: un refugio de biodiversidad en el litoral mesopotámico argentino. Biologica, Natureza, Conservación \& Sociedade 16: 147-159.

Deble, L.P., A.S. de Oliveira \& F.S. Alves. 2012. Two new species of Cypella (Iridaceae: Tigridieae) from Rio Grande do Sul, Brazil. Phytotaxa 71: 59-68. http://dx.doi.org/10.11646/phytotaxa.71.1.12

Deble, L.P., F.S. Alves, A. González \& A.S. de Oliveira. 2015a. Three new species of Cypella (Iridaceae) from South America, and taxonomic delimitation of $C$. suffusa Ravenna. Phytotaxa 236 (2): 101-120. http://dx.doi.org/10.11646/phytotaxa.236.2.1

Deble, L. P., F.S. Alves \& A.S. de Oliveira. 2015b. Three new species of the genus Cypella (Iridaceae, Tigridieae). Darwiniana, nueva série 3 (2): 235-253. http://dx.doi.org 10.14522/darwiniana.2015.31.666

Deble, L.P. \& F.S. Alves. 2017a. The type of Cypella herbertii subsp. brevicristata Ravenna (Iridaceae: Tigridieae). Balduinia 56: 20-26.

Deble, L.P. \& F.S. Alves. 2017b. Taxonomic novelties for the genus Cypella (Iridaceae): new species, synonymies and nomenclatural types. Kew Bulletin 72 (41): 1-18. 
Deble, L.P. \& F.S. Alves, Cypella trimontina.

Deble, L.P. \& F.S. Alves. 2020. Cypella (Iridaceae) What do we know about the diversity of the genus? Balduinia 66: 2-27.

Deble, L.P. 2021. Cypella cruenta (Iridaceae) the bloodstained Cypella. Balduinia 67: 2-9.

Goldblatt, P. \& J.C Manning. 2008. The Iris Family. Natural History and Classification. Portland: Timber Press. 290 pp.

Heald, W.F. 1951. Sky islands of Arizona. Natural History 60: 56-63.

Herbert, W. 1826. Tigridia Herberti supra $N^{\circ} 2599$. Cypella. Botanical Magazine 53: t. 2637 (text 2).

Herbest, R \& J.N. Santa Cruz. 1999. Mapa litoestratigráfico de la provincia de Corrientes. D'Orbignyana, 2, 1-69.

IUCN Standards and Petitions Committee. 2019. Guidelines for Using the IUCN Red List Categories and Criteria, version 14. IUCN Species Survival Commission. IUCN, Gland, Switzerland and Cambridge, UK. https://nc.iucnredlist.org/redlist/content/attachment files/RedListGuidelines.pdf

Kristensen M.J. \& J.L. Frangi. 1995. La Sierra de la Ventana: Una isla de biodiversidad. Ciencia Hoy 5: 25-34.
Meregalli, M. 1998. Gymnocalycium angelae spec. nov., eine neue Art aus Argentinien. Kakteen Sukkulenten 49 (12): 283-290.

Ravenna, P. 1977. Neotropical species threatened and endangered by human activity in the Iridaceae, Amaryllidaceae and allied bulbous families. In: Prance, G.T. \& Elias, T.S. (eds.) Extinction is forever. New York botanical Garden, New York, pp. 257-266.

Ravenna, P. 2003. Decisive proof on the validity of Amaryllis over Hippeastrum as mainly a South American genus, including new species and new records of Amaryllidaceae from Argentina, Brazil, and Paraguay. Onira Botanical Leaflets 9: 9-22.

Ravenna, P. 2009. A survey in the genus Cypella and its allies (Iridaceae). Onira Botanical Leaflets 12 (1): 1-11.

Thiers, B. 2021. Index Herbariorum: A global directory of public herbaria and associated staff. New york Botanical Garden's Virtual Herbarium. Available from: http:// sweetgum.nybg.org/ih/ (accessed 18 January 2021). 